A group of them can be instrumental in assisting in making the Western Hemisphere strong and influential, one of the least Utopian guarantees of a durable peace.

Further, they will all be in a position to assist with the creation not of a planned supreme State, which is the criterion of all values, but of a government of free responsible men, which will guide human relations and world affairs according to the laws of living Nature, as discovered and set forth by biologists.

\section{CONSTITUTIONAL ISSUES IN SOUTH-EAST AFRICA}

\author{
BY PROF. DARYLL FORDE \\ International African Institute
}

$\mathrm{T}$ HE recent announcement by the Secretary of State for the Colonies concerning the establishment of a standing Central African Council for the three territories of Southern Rhodesia, Northern Rhodesia and Nyasaland represents a further step in the attempt to secure an orderly solution of economic problems and political issues that have been intensified by the War. These three contiguous territories, each with an African population of about one and a half millions, share in varying degrees the problems that arise from the introduction of Western technology and white settlement in Africa. The issues are, however, by no means identical in each territory, and these differences, together with a conflict between the British Government and local white sentiment over long-term native policy, present serious obstacles to satisfactory constitutional development.

Southern Rhodesia, with a European population of about 69,000 , has had virtual Dominion status since 1923, and its executive government is responsible through the legislature to an electorate practically confined to whites. Although its constitution reserves to the Secretary of State for the Dominions considerable control over native affairs, this is of limited practical effect. The segregation of the native population and their exclusion from some occupations, in order to protect Europeans from native competition, are, as in South Africa, avowed objects of both the Government and the European population.

A substantial majority of the white population of about 13,000 in the Protectorate of Northern Rhodesia, most of them directly or indirectly depen. dent on the mining industries, share the sentiments of the white Southern Rhodesians. Despite the absence of any legal sanctions and the positive legislation of the Protectorate, they too are able, in practice, to impose restrictions on the employment and status of the native population.

In the Protectorate of Nyasaland, on the other hand, with a small white population of less than 2,000 planters, the principle of trusteeship and "the paramountcy of native interests" which is accepted by the British Government and so widely endorsed in Great Britain meets with less effective local opposition.

The whole problem is still further complicated by the fact that a very large proportion of the African male population, amounting to more than 100,000 in each of the territories, is employed as migrant labour on European farms and mines away from its native settlements. This has not only produced serious dislocation in native agriculture and community life, which is bitterly resented by champions of the African cause, but also, since there is a large-scale migration of labour across frontiers, calls for co-ordinated action in all the territories concerned.

The Southern Rhodesia Government has, over a number of years, pressed for the unification of the three territories under a responsible government which could, among other things, deal with the labour problems of the area as a whole. The evidence given to the Bledisloe Commission of 1938 revealed strong native opposition to amalgamation on which the Commission itself could not agree; but the impact of the War and the contribution of the white peoples of Africa to the defence of the Empire have sharpened the issue. The regional grouping of colonies in the interests of technical development and administrative e ficiency has gained increasing support, while General Smuts, in his speech at the end of last year, claimed for the Dominions a larger share of responsibility for the colonial territories in their respective spheres -in other words, the increasing influence of South Africa in the development of the southern African territories. The Prime Minister of Southern Rhodesia, Sir Godfrey Huggins, had earlier secured an undertaking that the question of amalgamation should not necessarily be postponed until after the War; while to meet the urgent needs of production and supply during the War, the Governors' Conference of these three south-east African territories has been supplemented by a joint secretariat.

The British Government now proposes to set up a standing Central African Council with a permanent secretariat, to deal with matters of common interest to the three territories. While only consultative, it is designed to provide machinery for the permanent co-operation of the administrative and technical services of the three Governments in such fields as industry, agriculture, labour, education and medical services. It is intended, in the words of the statement, that "leading unoficials in Southern Rhodesia and Nyasaland should be closely associated with the work of the Council", and it is recognized "that the Southern Rhodesia Government still adhere to their view that the three territories should be amalgamated". Amalgamation is, however, regarded as not being practicable "in existing circumstances", which, as Colonel Stanley explained in answer to questions in the House of Commons, refers not merely to the continuance of the War but also to "the difference in African policy between the territories".

At the same time it is proposed to take a further step forward in the constitutional development of the Northern Rhodesia Protectorate by increasing the uno i. cial membership of the Legislative Council from one to five, of whom three will represent the interests of the African community. The statement declares that "it is intended that African interests in the Legislative Council should be represented by Africans as soon as a suitable basis of representation can be built up", and the British Government is looking to the recently established Provincial African Councils as a political nursery for this development. This announcement concerning Northern Rhodesia, together with the express limitations on the powers of the Central African Council, makes it clear that the British Government still seeks to promote the growth of an educated and politically experienced African population which shall play its part in government. 